\title{
From Opinion 2/13 to Avotinsš: Recent Developments in the Relationship between the Luxembourg and Strasbourg Courts
}

\author{
Lize R. Glas* and Jasper Krommendijk** \\ KEYWORD S: Court of Justice of the European Union, European Court of Human Rights, \\ European Union accession to European Convention on Human Rights, \\ Bosphorus doctrine, Avotiņš v Latvia, Opinion 2/13
}

\section{INTRODUCTION}

With its recent judgment in Avotingš v Latvia of May 2016, the European Court of Human Rights (ECtHR) arrived at its long-awaited answer to Opinion 2/13 of the Court of Justice of the European Union (CJEU) of December 2014. ${ }^{1}$ In this Opinion, the CJEU prevented the European Union's (EU) accession to the European Convention of Human Rights (ECHR) by declaring the agreement on the accession of the EU to the ECHR incompatible with the specific characteristics and autonomy of EU law. This led to a discussion in the literature as to whether the ECtHR would apply the Bosphorus doctrine in the post-Opinion era as if nothing had happened. ${ }^{2}$ According to this doctrine, the ECtHR presumes that EU Member States do not depart from their obligations under the ECHR when implementing EU law, because EU law offers protection equivalent to the ECHR. Many commentators hinted at the possibility that the ECtHR would drop this presumption following Opinion 2/13 because of the critical approach of the CJEU towards the ECtHR in the Opinion. This was also based on a remark of the former President of the ECtHR, Dean Spielmann, that the Opinion was a 'great disappointment.' It is also telling that the first official contacts between

* Lize R. Glas, Assistant Professor, Faculty of Law, Radboud University (1.glas@jur.ru.nl).

** Jasper Krommendijk, Assistant Professor, Faculty of Law, Radboud University (j.Krommendijk@jur.ru.nl).

1 Avotinšs v Latvia Application No 17502/07, Merits and Just Satisfaction, 26 May 2016; Opinion 2/13, 18 December 2014.

2 Bosphorus v Ireland Application No 45036, Merits, 30 June 2006.

3 ECtHR, Annual Report 2014 (2015) at 6. Eeckhout mentioned that the relationship between both courts 'is unlikely to return to the past golden years of mutual respect and cooperation, let alone admiration': see Eeckhout, 'Opinion 2/13 on EU Accession to the ECHR and Judicial Dialogue: Autonomy or Autarky?' 
the CJEU and ECtHR since Opinion 2/13 were only resumed in March 2016 when a delegation of the ECtHR visited the CJEU. ${ }^{4}$ The ECtHR, however, chose to uphold the Bosphorus doctrine in Avotinšs, a case dealing with the Brussels I Regulation on the mutual recognition of civil law judgments. ${ }^{5}$ At first sight, the response of the ECtHR in Avotingš does not seem antagonistic and it seems that the ECtHR avoided entering into an arms race with the CJEU. Closer scrutiny of the judgment reveals, however, that this is not entirely true.

This short article examines the ECtHR's judgment in Avotinšs and will place it in the wider context of the relationship between the two highest European courts since Opinion 2/13. The article will therefore sketch the most notable recent developments that have had an impact on the relationship between Strasbourg and Luxembourg. Prior to examining these recent developments, the article will briefly discuss the relationship between the two courts as it could be characterized before Opinion 2/13 (Section 2). Section 3 examines the developments from the CJEU's perspective: it will discuss Opinion 2/13 together with the CJEU's recent trend of centring its fundamental rights case law around the EU Charter of Fundamental Rights ('Charter'), rather than around the ECHR. Section 4 tells the story from the perspective of the ECtHR. It first touches upon the ECtHR's recent practice of referring to CJEU judgments. It ends with an analysis of Avotinsš and the way in which the ECtHR applied the Bosphorus doctrine and dealt with the principle of mutual trust, which the CJEU referred to as being of 'fundamental importance in EU law' in Opinion 2/13.

\section{THE RELATIONSHIP BETWEEN LUXEMBOURG AND STRASBOURG BEFORE OPINION $2 / 13$}

Given that Opinion 2/13 made it impossible to proceed with the EU's accession on the basis on which it had been envisaged, the CJEU and the ECtHR must continue to shape their relationship themselves, as they have always done. They interact mostly through case law, but also through other channels. The earlier mentioned judgment of the ECtHR in Bosphorus is of special significance in this regard. Based on a description of the courts' interaction, as can be found in the literature and Bosphorus, this Section characterizes the two court's relationship before Opinion 2/13.

\section{A. Interaction through Case Law and other Means}

In the absence of an EU catalogue of fundamental rights, the CJEU started citing the rights protected in the ECHR in the mid-1970s. ${ }^{6}$ This enabled the CJEU to

(2015) 38 Fordham International Law Journal 955 at 990. Likewise Opinion 2/13 'may represent a turning point, and open a new confrontational phase': see Fabbrini and Larik, 'The Past, Present and Future of the Relation between the European Court of Justice and the European Court of Human Rights' (2016) Yearbook of European Law 1 at 27; Cherubini, 'The Relationship between the Court of Justice of the European Union and the European Court of Human Rights in View of the Accession' (2015) 16 German Law Journal 1375 at 1386.

4 CJEU, 'A Delegation from the European Court of Human Rights Visits the Court of Justice of the European Union', Press Release No 25/16, Luxembourg, 7 March 2016. There was thus no formal bilateral meeting in 2015 pursuant to the normal practice.

5 Council Regulation No 44/2001 of 22 December 2000 on jurisdiction and the recognition and enforcement of judgments in civil and commercial matters [2001] OJ L 12/1.

6 For example, C-36/75 Rutili [1975] ECR 1219 at para 32. 
conclude that fundamental rights constituted general principles of EU law because they resulted from the constitutional tradition common to the Member States. The CJEU accorded 'particular' or 'special significance' to the ECtHR in that regard. ${ }^{7}$ After the CJEU referred to ECtHR case law for the first time in 1996, such references to the ECHR became routine. ${ }^{8}$ In the 1990s, some inconsistencies between the fundamental rights case law of the two courts appeared, ${ }^{9}$ but, later, the CJEU went so far as to amend its own case law in response to judgments adopted by its counterpart. ${ }^{10}$ The CJEU thus not only mentioned Strasbourg case law, it followed it as well. ${ }^{11}$ In 2002, it was therefore concluded that the EU court 'applies the Convention as if its provisions formed an integral part of Community law' and, comparably, in 2006 that it applies 'ECHR standards diligently and conscientiously'. ${ }^{12}$ Indeed, the ECtHR's case law is the body of 'foreign' case law most cited in Luxembourg. ${ }^{13}$ Since the entry into force of the Charter in 2009, the key provision governing the relationship between that document and the ECHR is the homogeneity clause' in Article 52(3), which stipulates that ECHR-corresponding rights in the Charter must be given the same meaning and scope as those laid down by the ECHR. ${ }^{14}$ Article 53 furthermore guarantees a minimum level of protection equivalent to the ECHR.

Correspondingly, the ECtHR has followed and relied upon the Luxembourg case law to advance or adapt its interpretation of the ECHR. ${ }^{15}$ In its judgments, the

7 For example, C-47/87 and C-227/88 Hoechst [1989] ECR 2859 at para 13; C-540/03 Parliament v Council [2006] ECR I-5769 at para 35.

8 C-13/94, P v S and Cornwall County Council [1996] ECR I-2143 at para 16; Costello, 'The Bosphorus Ruling of the European Court of Human Rights: Fundamental Rights and Blurred Boundaries in Europe' (2006) 6 Human Rights Law Review 87 at 113; Douglas-Scott, 'A Tale of Two Courts: Luxembourg, Strasbourg and the Growing European Human Rights Acquis' (2006) 43 Common Market Law Review 629 at 646; Harpaz, 'The European Court of Justice and its Relations with the European Court of Human Rights: The Quest for Enhanced Reliance, Coherence and Legitimacy' (2009) 46 Common Market Law Review 105 at 108.

9 Lawson, 'Confusion and Conflict? Diverging Interpretations of the European Convention on Human Rights in Strasbourg and Luxembourg' in Lawson and de Blois (eds), The Dynamics of the Protection of Human Rights in Europe, Vol. III (1994) 219; Fabbrini and Larik, supra n 3 at 7-11. See specifically in the context of Article 8 ECHR, Rincón-Eizaga, 'Human Rights in the European Union. Conflict between the Luxembourg and Strasburg Courts regarding Interpretation of Article 8 of the European Convention on Human Rights' (2008) 11 Revista Colombiana de Derecho Internacional 119 at 119.

10 Costello, supra n 8 at 112.

11 Douglas-Scott, supra n 8 at 650; Harpaz, supra n 8 at 110.

12 Costello, supra n 8 at 114; Jacobs, 'Judicial Dialogue and the Cross-fertilization of Legal Systems: The European Court of Justice' (2003) 38 Texas International Law Journal 547 at 551; Scheeck, 'The Relationship between the European Courts and Integration through Human Rights' (2005) 65 Heidelberg Journal of International Law 837 at 871; Lock, 'The ECJ and the ECtHR: The Future Relationship between the Two European Courts' (2009) 8 The Law and Practice of International Courts and Tribunals 375 at 380 .

13 Douglas-Scott, supra n 8 at 650; Harpaz, supra n 8 at 109-10.

14 Opinion of AG Kokott in Case C-109/10 P Solvay v Commission [2011] I-10329 at para 252. In addition, Article 6(3) TEU stipulates that the provisions of the ECHR are general principles. De Witte argued on this basis that the EU is already bound by the ECHR: see De Witte, 'The Use of the ECHR and Convention Case Law by the European Court of Justice' in Popelier et al. (eds), Human Rights Protection in the European Legal Order: The Interaction between the European and the National Courts (2011) at 21-2. Jacobs, supra n 12 at 551; Scheeck, supra n 12 at 870. 
ECtHR demonstrates approval of and deference to the CJEU. ${ }^{16}$ Yet, the ECtHR does not refer as often to the CJEU as vice versa, although this has changed in the post-Charter years as is explained in Section 4.A. ${ }^{17}$ The comparably low number of references is not surprising, because the CJEU could use Strasbourg case law as an inspirational source for its fundamental rights protection jurisprudence. ${ }^{18}$ In 2006, the ECtHR became more aware of the CJEU and, some years later, it was noted that its references to Luxembourg seemed to be increasing. ${ }^{19}$

Besides this judicial dialogue through jurisprudence, the two courts also interact at bilateral meetings that were (and still are) organized alternately in Luxembourg and Strasbourg once or twice a year. During these informal meetings, the judges discuss issues that are of concern to both courts. Other interactions include invitations to give speeches, for example, on the occasion of the opening of the judicial year, conferences of joint interest, phone conversations and even private meetings. ${ }^{20}$

\section{B. The Bosphorus Doctrine}

In Bosphorus, ${ }^{21}$ the ECtHR had to reconcile the fact that Contracting States transfer sovereign powers to international organizations with their responsibility under the ECHR for measures taken by them to abide by their international legal obligations. ${ }^{22}$ To achieve this, the Strasbourg Court formulated the rule that it presumes that a state has not failed to fulfil its duties under the ECHR when implementing legal obligations flowing from the state's membership of an international organization, provided that two conditions have been fulfilled. ${ }^{23}$ First, the presumption only applies if the state has no discretion in how to implement these obligations. ${ }^{24}$ Secondly, the relevant international organization must protect fundamental rights in a manner which is equivalent to that for which the ECHR provides. ${ }^{25}$ The protection must be equivalent both in respect of the guarantees of substantive fundamental rights (that is, the substantive requirement) and the machinery for supervising fundamental rights enjoyment (that is, the procedural requirement). ${ }^{26}$ Importantly, if fundamental rights protection is manifestly deficient, the presumption can be rebutted. ${ }^{27}$

16 Douglas-Scott, supra n 8 at 641, 643; Harpaz, supra n 8 at 115.

17 Douglas-Scott, ibid. at 640.

18 Ibid. at 641.

19 Ibid. at 644; Harpaz, supra n 8 at 114-5; Lock, The European Court of Justice and International Courts (2015) at 219.

20 Jacobs, supra n 12 at 552; Butler, 'Interview: A Political Decision Disguised as Legal Argument? Opinion 2/13 and European Union Accession to the European Convention on Human Rights' (2015) 13 Utrecht Journal of International and European Law 104 at 105.

21 For an elaborate discussion of the facts, see Douglass-Scott, 'Bosphorus Hava Yollari Turizm Ve Ticaret Anonim Sirketi v. Ireland, Application No. 45036/98, Judgment of the European Court of Human Rights (Grand Chamber) of 30 June 2005, (2006) 42 E.H.R.R. 1' (2006) 43 Common Market Law Review 243; Kuhnert, 'Bosphorus - Double Standard in European Human Rights Protection?' (2006) 2 Utrecht Law Review 177.

22 Bosphorus, supra n 2 at paras 152-153.

23 Ibid. at para 156.

24 Ibid. at para 157.

25 Ibid. at paras 154-155.

26 Ibid. at para 160.

27 Ibid. at para 157. 
In Bosphorus, the ECtHR established that the presumption applied to the EU and found that it could not be rebutted in that case. ${ }^{28}$ After finding that the alleged violation was not the result of an exercise of discretion by the domestic authorities, the ECtHR went on to examine the substantive requirement. It attached considerable importance to the (then not yet binding) Charter and the CJEU's case law, which included extensive references to the ECHR and ECtHR jurisprudence. ${ }^{29}$ The EU, furthermore, fulfilled the procedural requirement because individuals are protected by actions brought before the CJEU by the EU states and institutions. Additionally, individuals can bring a domestic case to determine whether a state violated EU law, in which case the CJEU exercises supervision through the preliminary reference procedure. $^{30}$ If, conversely, a domestic court does not refer a question to the CJEU, even though the latter has not yet examined the right in issue, the domestic court rules without the 'full potential' of the supervisory machinery having been deployed. ${ }^{31}$ In this circumstance, the presumption does not apply. ${ }^{32}$ Having a supervisory machinery does, therefore, not suffice; it must also be deployed.

In general terms, the application of the Bosphorus doctrine means that the ECtHR does not scrutinize EU law and that it does not place itself above the CJEU or take over the CJEU's role of being arbiter of the validity of EU law. ${ }^{33}$ The ECtHR thus shows respect for the CJEU and the autonomy of the EU legal system and prevents a conflict with Luxembourg. ${ }^{34}$ To find that the presumption applies, the ECtHR has relied heavily on the CJEU's fundamental rights case law and the role of that court in supervising fundamental rights in the EU. ${ }^{35}$ Rather than being suggestive of conflict, the doctrine seems to be 'suggestive of a desired relationship of comity, or even cooperation'. 36

\section{Characterization}

The above description points to the European courts' willingness to listen, defer, show respect, prevent conflict and perhaps even to cooperate in the era before Opinion 2/13. ${ }^{37}$ Maintaining a relationship that is characterized by such a mindset is in both courts' interest because conflict could undermine their authority, while referring to each other possibly reinforces each court's legitimacy. ${ }^{38}$ Importantly, this

\section{(T)} Bosphorus Sovereign Immunity to Full Scrutiny?' in Sabitha (ed.), State Immunity: A Politico-Legal Study (2009).

36 Douglass-Scott, supra n 21 at 249. See also Lock, supra n 19 at 177-8, 180, 218.

37 Costello, supra n 8 at 89; Scheeck, supra n 12 at 871; Harpaz, supra n 8 at 115; Lock, supra n 19 at 177-8.

Ibid. at paras 165-166.

Ibid. at para 159.

Ibid. at paras 161-164; Michaud v France Application No 12323/11, Merits and Just Satisfaction, 6 December 2012 at para 111.

Michaud, supra n 30 at para 115.

Ibid. para 115. For instances of cases in which the doctrine was not applied, see section 4.B of this article.

Costello, supra n 8 at 88,103 .

Lock, supra n 19 at 180, 218.

Costello, supra n 8 at 102. See for a highly critical discussion of the judgment and doctrine: Besselink, The European Union and the European Convention on Human Rights after the Lisbon Treaty: From Douglas-Scott, supra n 8 at 664 . 
mindset is primarily based on comity, more than on a legal duty; ${ }^{39}$ this means that they can both change their mind when they wish. ${ }^{40}$ The character of the courts' future relationship, therefore, remains uncertain. ${ }^{41}$ To illustrate, it is interesting to recall that from interviews, held in 2004 at both courts, it transpired that 'in Strasbourg an unspoken concern about the EU remains and in Luxembourg some officials like to speculate on what will happen if the Charter enters into force, whereas in Luxembourg everyone fears that one day Strasbourg could declare void an ECJ decision'. 42

\section{LUXEMBOURG AND STRASBOURG: OPINION 2/13 AND CHARTER CENTRISM}

The first cracks in the courts' relationship appeared in December 2014 with Opinion $2 / 13$. Opinion $2 / 13$ has been extensively analysed and discussed. It is not the purpose of this article to repeat the arguments made. ${ }^{43}$ Instead, it will concentrate on the insights the Opinion can give into the relationship between the CJEU and the ECtHR.

\section{A. Opinion 2/13 and the CJEU's Distrust towards the ECtHR}

Importantly, Opinion 2/13 uncovers the concerns in Luxembourg about the sometimes far-reaching judgments of the ECtHR which could undermine the effectiveness of EU law. ${ }^{44}$ This tension has become particularly visible in the Area for Freedom, Security and Justice, especially in cases dealing with, for example, the Dublin Regulation and the European Arrest Warrant (EAW). It is mainly in this area that the CJEU has to balance, on the one hand, the uniformity, primacy and effectiveness of EU law and a system based on mutual trust and mutual recognition, with, on the other hand, fundamental rights concerns. By contrast, the ECtHR's sole objective is to guarantee fundamental rights. When pursuing this objective, it is arguable that the ECtHR does not always take the particularities of EU law sufficiently into account, including first and foremost mutual trust, at least in the eyes of some CJEU judges, and réferendaires. ${ }^{45}$ Judgments of the ECtHR, such as M.S.S. $v$ Belgium and Tarakhel $v$ Switzerland, can thus be difficult for the CJEU to square with EU law. It is thus not

39 See, however, Article 52(3) Charter and Article 6(3) TEU.

40 Lock, supra n 12 at 381.

41 Scheeck, supra n 12 at 873 .

42 Ibid. at 872.

43 See especially 'Special Section - Opinion 2/13: The E.U. and the European Convention on Human Rights' (2015) 16 German Law Journal 105-46; Storgaard, 'EU Law Autonomy Versus European Fundamental Rights Protection-On Opinion 2/13 on EU Accession to the ECHR' (2015) 15 Human Rights Law Review 485.

44 Lock, 'The Future of the European Union's Accession to the European Convention on Human Rights after Opinion 2/13: Is It Still Possible and Is It Still Desirable?' (2015) 11 European Constitutional Law Review 239 at 259; Groussot, Hettne and Petursson, 'General Principles and the Many Faces of Coherence: Between Law and Ideology in the European Union' in Studies of the Oxford Institute of European and Comparative Law Vol 21 (2016).

45 Krommendijk conducted 20 interviews with judges, référendaires and AGs at the CJEU in December 2014 about the how and why of citing the case law of the ECtHR in CJEU judgments: see Krommendijk, 'The Use of ECtHR Case Law by the Court of Justice after Lisbon: The View of Luxembourg Insiders' (2015) 22 Maastricht Journal of European and Comparative Law 812 at 831 . See also Groussot et al., supra $\mathrm{n}$ 44 at 24 . 
surprising that there have been divergences between the courts, as noted by some commentators. ${ }^{46}$ In those judgments, the ECtHR examined whether the return of an asylum seeker from one Member State to another on the basis of the Dublin Regulation, which is built on the idea of mutual trust between EU Member States, was consistent with the ECHR despite deplorable asylum conditions in the receiving Member State. The ECtHR held that such trust should be rebuttable. ${ }^{47}$

The CJEU's uneasiness towards the ECtHR is also visible in Opinion 2/13. In the Opinion, the CJEU granted the principle of mutual trust constitutional status by referring to it as being of 'fundamental importance in EU law' ${ }^{48}$ The CJEU subsequently determined that accession is problematic because it would treat the EU and the Member States in their relations with each other as 'normal' ECHR Contracting Parties. The CJEU added that the requirement under the ECHR to check another Member State's observance of fundamental rights despite mutual trust is liable to upset the underlying balance of the EU and undermine the autonomy of EU law. ${ }^{49}$ The CJEU thus essentially tried to withhold parts of EU law from the scrutiny of the ECtHR, thereby preventing future M.S.S. or Tarakhel rulings that could affect the effectiveness of EU law. ${ }^{50}$

\section{B. The CJEU's References to the ECtHR: Increasing Charter Centrism}

Opinion 2/13 also implies that the CJEU is reluctant to tie its own hands to the ECtHR. Rather, it wants to remain in control itself and reserve the possibility to give its own divergent interpretation of fundamental rights' norms. ${ }^{51}$ In Kadi I, the CJEU described the EC Treaty as 'an autonomous legal system which is not to be prejudiced by an international agreement'. ${ }^{52}$ In Opinion 2/13, the CJEU built on this formulation and held that 'the autonomy enjoyed by EU law ... requires that the interpretation of those fundamental rights be ensured within the framework of the

46 The CJEU followed suit in N.S., but it applied a seemingly stricter 'systemic deficiencies' test instead of looking at the individual's 'real risk' of inhuman or degrading treatment as the ECtHR does: see C-411/ 10 and C-493/10 N.S. and Others [2011] I-13905; Den Heijer, 'Joined Cases C-411 \& 493/10 NS v Secretary of State for the Home Department and ME v Refugee Applications Commissioner, Minister for Justice, Equality and Law Reform, Judgment of the Court (Grand Chamber) of 21 December 2011' (2012) 49 Common Market Law Review 1735 at 1747; Costello, 'Human Rights and the Elusive Universal Subject: Immigration Detention under International Human Rights Law' (2012) 19 India Journal of Global Legal Studies 257 at 271.

47 M.S.S. v Belgium Application No 30696/09, Merits and Just Satisfaction, 21 January 2011; Tarakhel v Switzerland Application No 29217/12, Merits and Just Satisfaction, 4 November 2014.

48 Opinion 2/13, supra n 1 at para 191; Lenaerts, 'The Principle of Mutual Recognition in the Area of Freedom, Security and Justice', Fourth Annual Sir Jeremey Level Lecture, University of Oxford (2015) at 6, available at: law.ox.ac.uk [last accessed 21 December 2016]; Gáspár-Szilágyi, 'Joined Cases Aranyosi and Căldăraru: Converging Human Rights Standards, Mutual Trust and a New Ground for Postponing a European Arrest Warrant' (2016) 24 European Journal of Crime, Criminal Law and Criminal Justice 197 at 204.

49 Opinion 2/13, supra n 1 at para 194.

50 Eeckhout, supra n 3 at 969; Groussot et al., supra n 44 at 24. In addition to N.S., there have been other cases in which asylum seekers challenged the Dublin system as being inconsistent with the Charter. For example, C-394/12 Abdullahi 10 December 2013. See also the still pending cases of C-155/15 Karim and C63/15 Ghezelbash.

51 Harpaz, supra $\mathrm{n} 8$ at 110 .

52 C-402/05 P and C-415/05 P Kadi [2008] I-06351 at para 316. 
structure and objectives of the EU' ${ }^{53}$ Opinion 2/13 could thus be interpreted as an illustration of the increasing Charter centrism and the tendency in the CJEU to autonomously interpret the Charter without reference to the ECHR and the case law of the ECtHR, a trend that can be contrasted with the CJEU's past practice. ${ }^{54}$ For CJEU judges and référendaires, citing Strasbourg less often is a way to underline the importance, the autonomy and the higher level of protection of the EU's 'own catalogue' of fundamental rights. ${ }^{55}$

After Opinion 2/13, the CJEU has indeed chosen to rely exclusively on the Charter in several judgments, even though there are still some judgments in which the case law of the ECtHR plays a large role. ${ }^{56}$ This is a trend that had started before Opinion 2/13, but it might have become more pronounced after Opinion 2/13. The case law of the ECtHR is cited in a more reserved way without referring to it as 'a source of inspiration' or being of 'special significance. ${ }^{57}$ In addition, the tone of the CJEU has become more formal. A particularly good illustration of the latter is the Grand Chamber judgment in J.N. about the detention of asylum seekers in the context of their deportation for reasons of public order and security. In J.N., the CJEU added that the review of the validity of EU secondary law 'must be undertaken solely in the light of the fundamental rights guaranteed by the Charter'. ${ }^{58}$ The CJEU went two steps further than its previous fundamental rights case law. First, by using the language of obligation ('must') and, secondly, by referring to the Charter in general. ${ }^{59}$ The CJEU also tried to minimize the effects of Article 52(3) of the Charter. It held for the first time, on the basis of the Explanations to the Charter, that consistency between the Charter and the ECHR should only be arrived at 'without thereby adversely affecting the autonomy of Union law' and its own. ${ }^{60}$

Charter centrism is particularly visible in judgments in which the CJEU does not refer to the case law of the ECtHR, even though a case was suitable for it. Such a possibility especially exists when the AG discusses ECtHR case law, ${ }^{61}$ or when referring to national courts or the parties explicitly signal relevant Strasbourg

53 Opinion 2/13, supra $\mathrm{n} 1$ at para 170.

54 Lenaerts and Gutiérrez Fons, 'The Place of the Charter in the EU Constitutional Edifice' in Peers et al. (eds), The EU Charter of Fundamental Rights: A Commentary (2014) at para 55.26.

55 Interviews as discussed in Krommendijk, supra n 45 at 832. See also De Búrca, 'After the EU Charter of Fundamental Rights: The Court of Justice as a Human Rights Adjudicator' (2013) 20 Maastricht Journal of European and Comparative Law 168 at 174-6; Bartolini and Biondi, 'Life as a Human Rights Court: Challenges and Developments in the EU Courts Activity in 2014' (2016) 22 European Public Law 3 at 24; Eeckhout, supra n 3 at 990; C-617/10 Åklagaren v Hans Åkerberg Fransson 26 February 2013, at para 87.

56 For an overview, see Krommendijk, 'The CJEU's Reliance on the Case Law of by the ECtHR since 2015: Opinion 2/13 as a Game Changer?' in Bribosia and Rorive (eds), Towards a Global and Integrated Approach of Human Rights: Promises and Challenges (2016).

57 Cf with supra nn 6 and 7.

58 C601/15 PPU J.N. 15 February 2016, at para 46. See subsequently C-543/14 Ordre des Barreaux Francophones et Germanophone and Others 28 July 2016, at para 23.

59 Earlier, the CJEU only held this in relation to specific provisions. First, in relation to Article 47 and later also 17, 7, 10 and 11 of the Charter. C-386/10 P Chalkor $v$ Commission [2011] ECR I13085 at para 51; C398/13 P, Inuit Tapiriit Kanatami 3 September 2015, at para 46.

60 See subsequently also C-294/16 PPU JZ 28 July 2016, at para 50.

61 For example, AG Sharpston in C-543/14, Ordre des Barreaux Francophones et Germanophone and Others 28 July 2016. 
judgments. ${ }^{62}$ One example is Schrems about the Commission's US Safe Harbour decision and data protection, where the CJEU only cited its own judgments, including its landmark judgment in Digital Rights. ${ }^{63}$ The Grand Chamber judgment in Delvigne provides another illustration. This case dealt with a reference for a preliminary ruling about French legislation depriving persons convicted of serious crimes of their right to vote. While Advocate General (AG) Cruz Villalón held that this case 'brings to mind immediately the case law of the [ECtHR]', which he lengthily examined, the CJEU only relied upon the Charter. ${ }^{64}$

The focus on the Charter instead of on the ECHR and ECtHR jurisprudence is also visible in CJEU judgments where Strasbourg is only referred to at the end as some sort of afterthought or crosscheck. The case law of the ECtHR does not seem to form part of the considerations leading to the interpretation of Charter provisions, but is only used by the CJEU to support the conclusions it already arrived at independently. J.N. is again the best example of a judgment in which the 'Strasbourgcheck' of the CJEU's analysis is included as a 'by the way' note ('Finally, it must be recalled that...') after an extensively analysis of Article 6 of the Charter (the right to liberty) and a detailed proportionality assessment in the context of Article 52(1) of the Charter. ${ }^{65}$ A similar approach was taken in $J Z$ where the Polish court referred to the case law of the ECtHR in relation to Article 5 of the ECHR and the CJEU felt compelled to devote some paragraphs to several ECtHR judgments, albeit in a rather selective way, in order to confirm its own Charter-based interpretation. ${ }^{66}$

As noted, there have been some exceptions to Charter centrism and, in many judgments, the CJEU still refers to the ECtHR and tries to align its own interpretation with the Strasbourg court. ${ }^{67}$ One recent example is Aranyosi. This case is particularly interesting, especially in the light of the CJEU's earlier statements on mutual trust in Opinion 2/13. Aranyosi concerned the admissibility of surrender of a Hungarian national by the Austrian judicial authorities to Hungary, where the prison conditions are deplorable. It dealt with the EAW Framework Decision and its exhaustive list of grounds for refusal, which does not explicitly provide for refusal in case of breaches of fundamental rights. There is only a general reference to fundamental rights in Article 1(3) in the sense that the Directive 'shall not have the effect of modifying the obligation to respect fundamental rights'. AG Bot did not refer to the homogeneity clause of the Charter (Article 52(3)) and adopted a rather narrow textual reading of the Decision, emphasising the limited grounds for non-execution, which favoured the effectiveness of the system set-up by the EAW Framework Decision. The CJEU, however, opted for a more fundamental rights and ECHR

62 For example, C-615/13 P, Client Earth 16 July 2015, at para 29.

63 C362/14, Schrems 6 October 2015, at para 193.

64 Opinion of AG Cruz Villalón in C-650/13, Delvigne 6 October 2015, at para 109.

65 The CJEU could almost not avoid reflecting upon the case law of the ECtHR, because the referring Dutch court explicitly relied on particular judgments of the ECtHR in its reference: see J.N., supra n 58 at paras 50-77; and interviews as discussed in Krommendijk, supra n 45 at 832.

$66 J Z$, supra n 60 at para 21.

67 For example, Case C-205/15, Toma 30 June 2016; C-583/13 P, Deutsche Bahn and Others v Commission 18 June 2015. 
consistent reading of the EAW, to the delight of many observers and academics. ${ }^{68}$ The CJEU stipulated, with references to Strasbourg case law, that the execution of a EAW must be postponed (but not abandoned altogether) if there is a real risk of inhuman or degrading treatment for the individual concerned because of deficient detention conditions in the requesting Member States. ${ }^{69}$ Aranyosi thus illustrates that the CJEU is carefully avoiding a direct clash with the ECtHR and even tried to, according to Gáspár-Szilágyi, 'heal some of the wounds created by Opinion 2/13, ${ }^{70}$ In earlier cases such as N.S. and Abdullahi, the CJEU had applied a seemingly stricter test (of 'systemic deficiencies') rather than the test which the ECtHR applies (looking at the individual's 'real risk' of inhuman or degrading treatment). ${ }^{71}$ In Aranyosi, the CJEU also opted for the latter. This judgment might thus be some sort of gesture of comity towards the ECtHR, possibly in anticipation of the ECtHR's ruling in Avotiņs. ${ }^{72}$

This short overview shows that the CJEU has recently been citing Strasbourg less and in a more reserved way, while also being more critical about the necessity to do so. This does not, however, mean that the CJEU has entered into open warfare. The changing tone is subtle and at the same time partly masked by many judgments, such as Aranyosi, which still give the ECHR and ECtHR jurisprudence a prominent role. ${ }^{73}$

\section{STRASBOURG AND LUXEMBOURG: CONTINUED REFERENCES AND CRITICAL REAFFIRMATION OF THE BOSPHORUS DOCTRINE}

Strasbourg insiders have looked at the recent developments in Luxembourg with some unease and frustration. The reactions to Opinion 2/13 were downright critical. As noted in the introduction, Dean Spielmann stated that it was 'a great disappointment'. He added that 'the principal victims will be those citizens whom this opinion ... deprives of the right to have acts of the European Union subjected to the same external scrutiny as regards respect for human rights as that which applies to each Member State. ${ }^{74}$ Likewise, a recent report on the future of the ECHR by the Steering Committee for Human Rights ( $\mathrm{CDDH})$ referred to the 'growing importance of the Charter ... to the detriment of the Convention' in the CJEU's case law. ${ }^{75}$ These Strasbourg perceptions have been interpreted by some as a growing

68 See, for example, Fair Trials Letter to the Commisssioner for Justice, Consumers and Gender Equality of the European Commission, 'AG's Bot Opinion in Aranyosi and Căldăraru. A Threat to Justice in Europe', 10 March 2016, available at: fairtrials.org [last accessed 21 December 2016]; Gáspár-Szilágyi, supra n 48 at 205-6.

69 C-404/15 and C-659/15 PPU Aranyosi and Căldăraru 5 April 2016, at paras 86-91.

70 Gáspár-Szilágyi, supra n 48 at 217-8.

71 Den Heijer, supra n 46.

72 One interviewed CJEU insider noted that a reason to explicitly cite the ECtHR is to show Strasbourg that the CJEU still deserves the Bosphorus presumption. Another interviewee, however, held that the CJEU is not referring to the ECtHR to make judges in Strasbourg happy. For a discussion of those interviews, see Krommendijk, supra n 45 at 826 .

73 The different approaches of the CJEU stem from the absence of a uniform practice or methodology and can primarily be attributed to the composition of a Chamber and the dynamics within a certain formation: see ibid. at $816-7$.

74 ECtHR, supra n 3.

$75 \mathrm{CDDH}$, 'Report on the Longer-term Future of the System of the European Convention on Human Rights', CM(2015)176-add1final, 3 February 2016, at para 179. 
eagerness on the part of the ECtHR to critically take stock of EU law. This section will analyse how the ECtHR has dealt with EU law in this context since Opinion 2/ 13.

\section{A. The ECtHR's References to the CJEU}

In light of the CJEU's Charter centrism, the question can be posed whether the ECtHR's references to the CJEU case law on the Charter and the Charter itself have decreased since the latter delivered Opinion 2/13. This seems to be an unlikely development, as the ECtHR actually started to refer to EU law more when the Charter came into play, and even more when it became binding. ${ }^{76}$ This hypothesis is confirmed by a quick scan of Strasbourg references to the Charter in the (approximately) 19-month periods of 4 May 2013 to 17 December 2014 and 18 December 2014 to 2 August 2016 (the Opinion was adopted on 18 December 2014). ${ }^{77}$ In the first period, the ECtHR referred to the Charter seven times in the 'relevant international documents' section of its judgment and made five references in both that section and 'the law' section. These figures are, respectively, 17 and four for the more recent period, in which the ECtHR made references in just the 'the law' section two times. Although the implications of this review are limited because it only looks at Charter references and not other relevant legislation or Luxembourg case law, it does show that the ECtHR does not seem to respond to Opinion 2/13 by decreasing the number of references to EU law. It should also be noted that any sustained change would be hard to pinpoint, because the Strasbourg Court does not refer to its Luxembourg counterpart very often anyhow. ${ }^{78}$

It is only logical that the Luxembourg trend is not mirrored in Strasbourg, because with the Charter-the EU's own fundamental rights catalogue, the relevance of the ECHR for the CJEU has decreased, whereas the Charter has made EU law more relevant to the ECtHR. The Charter, as a comparably modern human rights treaty, is particularly relevant to the ECtHR because the ECHR is a living instrument, to be interpreted in present-day conditions, ${ }^{79}$ The ECtHR can rely upon the Charter to show contemporary consensus and hence modernize its own treaty. ${ }^{80}$ In addition, some provisions in the Charter give a higher level of protection than the ECHR, which could be beneficial for the ECtHR to bolster its own case law. ${ }^{81}$ Another explanation for why it is not logical that the trend would be mirrored in Strasbourg is that the CJEU's case law has increased in relevance for the ECtHR as the CJEU has been seized with more cases in which fundamental rights play an

76 Lock, supra n 19 at 214-5. See 'Introduction' in Lock, 'The influence of EU law on Strasbourg Doctrines' (2016) 41 European Law Review 804 at 806.

77 Two different searches were conducted on HUDOC for the periods mentioned above. The following search terms were used: 'Charter of Fundamental Rights' and 'Charte des droits fondamentaux'. Only references to the document by the ECtHR were taken into consideration and not references by the parties or in a separate opinion.

78 See section 2.A of this article.

79 X. and Others v Austria Application No 19010/07, Merits and Just Satisfaction, 19 February 2013 at para 139.

80 Lock, supra n 19 at 214-5; Lock, supra n 76.

81 Spielmann, 'Foreword' in Dzehtsiarou et al. (eds), Human Rights Law in Europe (2014) i at vii-xxi. 
important role after the entry into force of the Charter. ${ }^{82}$ In sum, even though Opinion 2/13 was unwelcome to the ECtHR, it has not changed the potential relevance of EU law to it.

\section{B. The Bosphorus Doctrine after Avotiņs}

As was noted in Section 2, the Bosphorus doctrine can be interpreted as an expression of the good relationship between the CJEU and the ECtHR. Opinion 2/13 may, however, have troubled that relationship and, as was indicated in the introduction, the question therefore arose whether the ECtHR would continue to apply the doctrine to the EU. This question became pertinent because President Spielmann stated that, with accession blocked, '[m] ore than ever ... the onus will be on the Strasbourg Court to do what it can in cases before it to protect citizens from the negative effects of this situation. ${ }^{83}$ This section answers that question and, more generally, scrutinizes the judgment from the perspective of the relationship between the two courts since Opinion 2/13.

Different scenarios as to what the ECtHR would do with the Bosphorus doctrine after Opinion 2/13 were possible. ${ }^{84}$ The first scenario was that the ECtHR would apply the doctrine in the post-Opinion era as if nothing had happened. Some considered that scenario as unlikely because Opinion 2/13 'revealed a potentially dismissive approach by the CJEU vis-a-vis the ECtHR, and the unwillingness of the former to subject itself to external review by the latter. ${ }^{85}$ Two other scenarios were also possible. Most unrealistically, the ECtHR could decide to no longer apply the Bosphorus doctrine to the EU. ${ }^{86}$ More realistically, it could apply the doctrine more stringently. ${ }^{87}$ The scenario where the ECtHR would abandon the doctrine is unrealistic, ${ }^{88}$ because the doctrine suggests that the EU provides equivalent protection for fundamental rights and Opinion 2/13 does not change this. On the contrary, now that the Charter has become binding, the (CJ)EU is probably more aware of the importance of protecting fundamental rights than ever. ${ }^{89}$ The CJEU's Charter centrism does not necessarily invalidate this proposition, because the ECtHR demands 'not identical but "comparable" protection..$^{90}$ Therefore, even if Charter centrism would mean that the protection standards are merely comparable, the doctrine can still be applied

82 Lock, supra n 76.

83 ECtHR, supra n 3.

84 See also Fabbrini and Larik, supra n 3 at 28.

85 Ibid. See also Mole, 'Can Bosphorus be Maintained?' (2015) ERA Forum 467 at 480.

86 See also Polakiewicz, 'Speeches of the Director, Directorate of Legal Advice and Public International Law: The Future of Fundamental Rights Protection without Accession', 26 June 2015, available at: coe.int [last accessed 21 December 2016]; Morijn, 'After Opinion 2/13: How to Move on in Strasbourg and Brussels?' EUtopia law, 5 January 2015, available at: eutopialaw.com [last accessed 21 December 2016].

87 See also Butler, supra n 20 at 108; Lock, 'Will the Empire Strike back? Strasbourg's Reaction to the CJEU's Accession Opinion', VerfBlog, 30 January 2015, available at: verfassungsblog.de/will-empirestrike-back-strasbourgs-reaction-cjeus-accession-opinion/ [last accessed 21 December 2016]; Fabbrini and Larik, supra $\mathrm{n} 3$ at 29.

88 See also Butler, supra n 20 at 108.

89 See also Bergé, 'Avotins ou le calme qui couve la tempête', GDR CNRS ELSJ, 26 May 2016, available at: gdr-elsj.eu [last accessed 21 December 2016].

90 Michaud, supra n 30 at para 103. 
and, in the event that the standards diverge more drastically in the future, the ECtHR can always find that the presumption is rebutted. Moreover, preventing conflict remains in both courts' interest. ${ }^{91}$

With Avotinšs, the unrealistic scenario did not materialize: the ECtHR applied the Bosphorus doctrine. ${ }^{92}$ Did the ECtHR nevertheless apply the doctrine in a stricter fashion than it had before? Because there are only very few rulings in which the Bosphorus doctrine plays a role, it is hard to give a definite answer. ${ }^{93}$ Nevertheless, the four other decisions in which the ECtHR applied the doctrine to the EU, as well as Bosphorus itself, provide some material for comparison, as do the cases in which the Bosphorus doctrine was eventually not applied to the EU. Furthermore, a close consideration of the judgment makes it possible to draw some conclusions.

In the decisions in Mayenne and Biret, the ECtHR presumed equivalent protection mainly with reference to Bosphorus. ${ }^{94}$ In the decision in Kokkelvisserij, it held that the sole fact that the applicant could not respond to the AG's opinion in preliminary ruling proceedings did not make the protection afforded manifestly deficient, meaning that the presumption was not rebutted. ${ }^{95}$ Lastly, in the decision in Povse, the ECtHR assumed there was no discretion because the CJEU had ruled so. Furthermore, the ECtHR did not consider it problematic that the CJEU had not dealt with the alleged violation in a preliminary ruling, because the CJEU had stipulated that it was for domestic courts to protect the rights of individuals in the relevant context and because the applicants had not invoked their rights before domestic courts even though they could have done so. ${ }^{96}$ These decisions affirm, as was also concluded in Section 2, that the ECtHR approves of how the CJEU discharges its task, avoids stepping in the CJEU's shoes and defers to the CJEU's findings. ${ }^{97}$ In some other EU-related cases, the ECtHR discussed the possibility of applying the Bosphorus doctrine, but eventually decided against it. One example is the earlier mentioned case of M.S.S. where there was discretion for EU Member States in the implementation of their EU law obligations. ${ }^{98}$ Importantly, the ECtHR did not reach this decision because of a fundamental rights flaw in the EU. These other cases, therefore, also do not disclose any firm criticism by Strasbourg of Luxembourg.

91 See also Fabbrini and Larik, supra n 3 at 30, 35; Section 2.C of this article.

92 Avotingš, supra n 1 at para 125.

93 The doctrine can also be applied to other international organizations than the EU (cases in which the Court applied the doctrine to other international organizations were not taken into consideration in this article), see Ryngaert, 'Oscillating between Embracing and Avoiding Bosphorus: The European Court of Human Rights on Member State Responsibility for Acts of International Organisations and the Case of the European Union' (2014) European Law Review 176.

94 Coopérative des agriculteurs de Mayenne v France Application No 16931/04, Decision, 10 October 2006; Biret $v 15$ States Application No 13762/04, Decision, 9 December 2008.

95 Kokkelvisserij $v$ The Netherlands Application No 13645/05, Admissibilty, 20 January 2009.

96 Povse v Austria Application No 3890/11, Admissibility, 18 June 2013, at paras 82, 84-8.

97 See also Lock, supra n 19 at 204.

98 M.S.S., supra n 47; Michaud, supra n 30 (not applied because domestic courts failed to make a reference for a preliminary ruling); Collony v 15 EU Member States Application No 73274/01, Admissibilty, 9 December 2008; Andreasen v 27 EU Member States Application No 28827/11, Admissibility, 31 March 2015 (not applied because the complaints were really directed against decision of EU institutions). 


\section{(i) The facts}

The complaint in Avotinšs was brought by a Latvian national, who had signed an acknowledgement of debt with a company registered in Cyprus. When he did not repay his debt in time, the company sued him in a Cypriot court. Even though the applicant had been duly notified of the hearing according to the Cypriot court, he did not appear. It, therefore, ruled in his absence and ordered him to pay the debt and interest. Subsequently, the company started proceedings in a Latvian court requesting recognition and enforcement of the Cypriot judgment. The first-instance Latvian court ceded to the company's request and ordered the recording of a charge against the applicant's property in the land register. When the applicant learnt of the Cypriot judgment and Latvian court's enforcement order, he only appealed to the latter, but in vain. The applicant contended that the recognition and enforcement of the Cypriot judgment in Latvia breached the Brussels I Regulation. ${ }^{99} \mathrm{He}$ argued inter alia that Article 34(2) of that Regulation had not been abided by. That provision requires that a judgment given in default in another Member State is not recognized if the defendant was not served with the document instituting the proceedings in sufficient time and in such a way as to enable him to arrange for his defence, "unless the defendant failed to commence proceedings to challenge the judgment when it was possible to do so'. Before the ECtHR, the applicant complained that the Latvian courts had violated Article 6(1) of the ECHR because they had enforced the judgment of the Cypriot court, which was the product of court proceedings that had disregarded his defence rights. A Chamber found that there had been no violation. ${ }^{100}$ The case was then referred to the Grand Chamber of the ECtHR by the applicant and the Grand Chamber accepted the referral.

\section{(ii) The presumption of equivalent protection: discretion and deployment of the}

\section{supervisory mechanism}

As for the first condition for applying the Bosphorus doctrine, the ECtHR concluded that the domestic courts had no discretion to refuse to recognize the Cypriot judgment under Article 34(2) of the Brussels I Regulation. The ECtHR reached this conclusion because a 'fairly extensive body of [CJEU] case-law' on the provision clarified that it 'did not confer any discretion on the court from which the declaration of enforceability was sought. ${ }^{101}$ As it did in the decision in Povse, discussed above, the ECtHR assumed that there was no discretion because the CJEU had ruled so. ${ }^{102}$ Therefore, the ECtHR maintained its deferential stance towards the CJEU on this point.

The earlier finding of the Chamber, which also concluded that there was no discretion, was called 'surprising' by one observer who proposed that this 'may have been one of the reasons why [the case] was referred to the Grand Chamber'. ${ }^{103}$ This ment of judgments in civil and commercial matters [2001] OJ L 12/1.

100 Avotiņš v Latvia Application No 17502/07, Merits and Just Satisfaction, 25 February 2014.

101 Avotiņ̌s, supra n 1 at para 106 (emphasis added).

102 Ibid.

103 Düsterhaus, 'Judicial Coherence in the Area of Freedom, Security and Justice. Squaring Mutual Trust with Effective Judicial Protection' (2015) 8 Review of European Administrative Law 151 at 169. 
observer disagreed with the Chamber's conclusion and found support in the dissenting opinion of Judges Ziemeke, Bianku and de Gaetano which concluded, with reference to the ground for refusal in Article 34(2), that 'the applicable EU law does not provide for blind automaticity as concerns the execution of judgments' ${ }^{104}$ This, however, as the Chamber and Grand Chamber rightly established, does not mean that domestic courts also had discretion under Article 34(2), because Article 34(2) provides that a 'judgment shall not be recognised' if certain factual circumstances apply. ${ }^{105}$ While domestic courts do not have discretion, they have two options: to either recognize a judgment or not (and which option is adopted will depend on the facts). Domestic courts, therefore, do not have any 'margin of manoeuvre, ${ }^{106}$ as Member States do have, for example, in the Dublin procedure where the applicable Regulation provides that they 'may' use the 'sovereignty' clause. ${ }^{107}$

As regards the second condition for applying the Bosphorus doctrine, the Grand Chamber of the ECtHR did not mention the requirement that the EU should provide comparable substantive fundamental rights guarantees; it only discussed the procedural requirement and specifically whether the EU's supervisory mechanism had been fully deployed. ${ }^{108}$ The Grand Chamber explicitly downplayed this procedural condition. In Michaud, the ECtHR had determined that the Bosphorus presumption did not apply, because a domestic court had refrained from submitting a preliminary reference even though the CJEU had never examined the Convention rights in issue. ${ }^{109}$ In Avotingš, the ECtHR held that this condition should not be applied with 'excessive formalism. ${ }^{110}$ Rather it stipulated that

it would serve no useful purpose to make the implementation of the Bosphorus presumption subject to a requirement for the domestic court to request a ruling from the CJEU in all cases without exception, including those cases where no genuine and serious issue arises with regard to the protection of fundamental rights by EU law, or those in which the CJEU has already stated precisely how the applicable provisions of EU law should be interpreted in a manner compatible with fundamental rights. ${ }^{111}$

The actual test that the ECtHR subsequently conducted was rather formalistic and superficial. The ECtHR considered that the applicant had paid insufficient

Article 3(2) Council Regulation No 343/2003 establishing the criteria and mechanisms for determining the Member State responsible for examining an asylum application lodged in one of the Member States by a third-country national [2003] OJ 50/1 (emphasis added). See also ibid. at para 107.

Avotinšs, ibid. at para 108. The ECtHR probably does not mention the substantive requirement because it discusses the content of the matter when contemplating whether the presumption of equivalent protection can be rebutted.

109 In addition, the ECtHR paid attention to the question whether such a referral was necessary in the light of the case law of the CJEU. It held that there was such a need because the CJEU had only examined the obligations for lawyers to report suspicion in the light of the right to a fair trial (Article 6 ECHR), but not the rights of the lawyer under Article 8 ECHR: see Michaud, supra n 30 at paras 114-5. 
attention to Article 34(2) of the Brussels I Regulation and its compatibility with fundamental rights and had refrained from requesting the Latvian Supreme Court to make a preliminary reference to the CJEU on this matter. The ECtHR thus concluded that the absence of a reference by the Latvian court was 'not a decisive factor' and held that the Bosphorus presumption applied. ${ }^{112}$

Several observations can be made about the approach of the ECtHR. First, the formalistic approach taken is nothing new per se, but it is the first time that the ECtHR explicitly acknowledged that the procedural criterion for the application of the Bosphorus doctrine should not be applied stringently. ${ }^{113}$ In doing so, the ECtHR appeared to align its approach more closely to the case law of the CJEU, because the quoted fragment implicitly refers to Luxembourg's CILFIT exceptions to the obligation for the highest national courts to refer under Article 267 of the Treaty on the Functioning of the European Union (TFEU), including the doctrine of acte éclairé and acte clair. ${ }^{114}$ Secondly, the ECtHR did not-understandably so from its point of view-examine more substantively whether the Supreme Court had an obligation to submit a reference for a preliminary ruling of its own motion. ${ }^{115}$ The ECtHR generally leaves such questions to the CJEU. ${ }^{116}$ Thirdly, and most importantly, the ECtHR placed much emphasis on the question whether there had been a request for a preliminary reference by one of the parties. This reliance on the (absence of a) request of one of the parties is in line with the ECtHR's earlier judgments in Dhahbi and Schipani in which it established a violation of Article 6(1) of the ECHR (right to a fair trial) on the basis of the failure of the highest Italian court to provide a statement of reasons for its refusal to request a preliminary ruling from the CJEU despite requests from the parties. ${ }^{117}$ A request from one of the parties is, however, unimportant from the perspective of EU law, because the CJEU famously ruled in CILFIT

112 Ibid. at para 111.

113 The ECtHR applied the Bosphorus presumption in Povse, because the Austrian Supreme Court made a reference. The ECtHR did, however, not examine whether the requested ruling also paid sufficient attention to fundamental rights, as the applicants argued: see Povse, supra n 96 at paras 65 and 77. Likewise, the ECtHR applied the presumption in Mayenne even though the French Council of State had not requested a preliminary ruling from the CJEU. The difficulty with this (short) decision declaring the complaint inadmissible is that the ECtHR does not conduct a substantive analysis of its Bosphorus criteria: see Mayenne, supra n 94 at para 5. See also Lock, 'Beyond Bosphorus: The European Court of Human Rights' Case Law on the Responsibility of Member States of International Organisations under the European Convention on Human Rights', (2010) 10 Human Rights Law Review 529 at 529-45, 540-1; Lock, supra n 19 at 204.

114 Article 267(3) TFEU obliges courts or tribunals 'against whose decisions there is no judicial remedy' to refer when they have doubts about the the interpretation and validity of EU law. Such a reference is not required if a question on EU law is not relevant for the outcome of the dispute, if the point of EU law has already been dealt with by the CJEU (acte éclairé) or if the correct application of EU law 'may be so obvious as to leave no scope for any reasonable doubt' (acte clair).

115 This is understandable because the ECtHR generally does not examine the correctness of the way in which national courts dealt with their obligation to refer, since this would mean that it expresses itself upon the interpretation and application of EU law: see Bosphorus, supra n 1 at para 43; Dhahbi $v$ Italy Application No 17120/09, Merits and Just Satisfaction, 8 April 2014, at para 31.

116 In Ferreira da Silva, the CJEU, for example, hinted at a breach of Article 267 TFEU by the highest Portuguese court: see C-160/14 Ferreira da Silva, 9 September 2015.

117 Dhahbi, supra n 115; Schipani and Others v Italy Application No 38369/09, Merits and Just Satisfaction, 21 July 2015. 
that Article 267 of the TFEU 'does not constitute a means of redress available to the parties to a case. ${ }^{118}$ On the contrary, it is entirely a court-to-court procedure, which is 'completely independent of any initiative by the parties'. ${ }^{119}$ The reliance by the ECtHR on the request thus seems to run counter to the way in which the CJEU construes the preliminary reference procedure. ${ }^{120}$

Interestingly, the ECtHR also held that it performs the Dhahbi test on the basis of the criteria and CILFIT exceptions developed by the CJEU, while it conducts the Bosphorus test 'in accordance with conditions which it has itself laid down'. ${ }^{121}$ By explicitly referring to its own conditions in relation to Bosphorus, the ECtHR seems to affirm that it is essentially up to the Strasbourg Court to determine whether the EU legal system is indeed equivalent. The ECtHR is thus showing its teeth with this rhetoric. At the same time, the Bosphorus test as applied in Avotiňs shows that the ECtHR's bark is worse than its bite, because the procedural criterion was applied less strictly than in earlier Bosphorus cases.

\section{(iii) Rebuttal presumption of equivalent protection: mutual trust and protection in the applicant's case}

Before determining whether the protection of fundamental rights was manifestly deficient in the Avotiņš' case, the Grand Chamber made some general remarks regarding mutual trust. This is one of the most interesting and important parts in Avotinšs, especially because the absence of a reference to this constitutional principle in the accession agreement was one of the more principled reasons for the CJEU to halt the EU's accession to the ECHR. Avotinsš underscores once more that the ECtHR remains willing to also (indirectly) scrutinize EU measures based on mutual recognition and mutual trust as it did earlier in M.S.S. and Tarakhel. ${ }^{122}$ The ECtHR was obviously aware of the sensitivities its willingness causes and explicitly mentioned that it is 'mindful of the importance' of mutual recognition mechanisms and mutual trust. $^{123}$ At the same time, the ECtHR held that those mechanisms must not infringe fundamental rights. ${ }^{124}$ It is in the context of the latter that the ECtHR made a crucial

Case C-283/81 CILFIT [1982] ECR 3415 at para 9.

Case C210/06 Cartesio, 16 December 2008, at para 90. See also Broberg, 'Preliminary References as a Right - but for Whom? The Extent to which Preliminary Reference Decisions Can be Subject to Appeal' (2011) 36 European Law Review 276.

The implication of this is that national courts are required to pay more attention to parties' requests than before because they have to explicitly address such requests, at least when they are specific and pertinent. Some authors even claim that this comes close to recognition by the ECtHR that a reference for a preliminary ruling constitutes an autonomous subjective right of the parties in national court proceedings: see Opinion of AG Bot in Case C-2/06 Kempter [2008] ECR I-411 at para 97; Lacchi, 'The ECtHR's Interference in the Dialogue between National Courts and the Court of Justice of the EU: Implications for the Preliminary Reference Procedure' (2015) 2 Review of European Administrative Law 95 at 111. Krommendijk, “Open sesame!” Improving Access to the CJEU by Obliging National Courts to Reason Their Refusals to Refer' (2017) European Law Review (forthcoming).

Avotiņšs, supra $\mathrm{n} 1$ at para 110 .

See earlier, for example, M.S.S., supra n 47; Tarakhel, supra n 47.

Avotiņšs, supra $\mathrm{n} 1$ at para 113 .

Ibid. at para 114 . 
point, which seems to have received almost no attention in the initial enthusiasm that the ECtHR maintained the Bosphorus doctrine. ${ }^{125}$ It is also in relation to this point that the implicit Strasbourg criticism of Opinion 2/13 can be seen. Given the importance of this part of the judgment it is worthwhile reproducing it in full:

However, it is apparent that the aim of effectiveness pursued by some of the methods used results in the review of the observance of fundamental rights being tightly regulated or even limited. Hence, the CJEU stated recently in Opinion 2/13 that "when implementing EU law, the Member States may, under EU law, be required to presume that fundamental rights have been observed by the other Member States, so that ..., save in exceptional cases, they may not check whether that other Member State has actually, in a specific case, observed the fundamental rights guaranteed by the EU” ... Limiting to exceptional cases the power of the State in which recognition is sought to review the observance of fundamental rights by the State of origin of the judgment could, in practice, run counter to the requirement imposed by the Convention according to which the court in the State addressed must at least be empowered to conduct a review commensurate with the gravity of any serious allegation of a violation of fundamental rights in the State of origin, in order to ensure that the protection of those rights is not manifestly deficient. ${ }^{126}$

The ECtHR subsequently used two further paragraphs to state more or less the same albeit in slightly different words. The conclusion is thus that national court judges cannot refrain from examining fundamental rights complaints 'on the sole ground that they are applying EU law. ${ }^{127}$

It is remarkable that the ECtHR uses such blunt language. It chose, for example, not to mention that Article 34(2) of the Brussels I Regulation requires domestic courts to refuse to recognize a judgment when the rights of defence are not effectively respected. ${ }^{128}$ In addition, the ECtHR only referred explicitly to recitals 16 and 17 of the Brussels I Regulation which underscore the necessity of automatically recognizing such judgments. In doing so, the ECtHR seemed to suggest that there is no room for fundamental rights considerations in the Brussels I Regulation, despite the fact that recital 18 addresses this explicitly. ${ }^{129}$ The ECtHR could have chosen a more reconciliatory tone in its judgment by, for example, anchoring its considerations more explicitly in EU law itself. More specifically, the ECtHR could have stressed that the CJEU has given national courts room to deviate from the automatic character required by mutual trust in order to protect fundamental rights in the, albeit

Requejo, 'Avotins v. Latvia: Presumption of Equivalent Protection not Rebutted', ConflictofLaws.net, 24 May 2016, available at: conflictoflaws.net/2016/avotins-v-latvia-presumption-of-equivalent-protectionnot-rebutted/ [last accessed 2 December 2016].

127 Ibid. at para 116.

128 See C-283/05 ASML Netherlands BV v SEMIS [2006] ECR I-12041 at para 20.

129 'However, respect for the rights of the defence means that the defendant should be able to appeal in an adversarial procedure, against the declaration of enforceability, if he considers one of the grounds for non-enforcement to be present. Redress procedures should also be available to the claimant where his application for a declaration of enforceability has been rejected.' 
different policy area, of criminal law and the EAW. ${ }^{130}$ One potential explanation for the ECtHR's reticence is that references to those fundamental rights considerations might give the impression that there was discretion for national courts, even though, as argued above, this was not the case. ${ }^{131}$

The ECtHR was further rather critical when contemplating whether the presumption of equivalent protection could be rebutted. In Bosphorus, it discussed this matter in only one paragraph and found that the presumption could not be rebutted, with reference to the nature of and general interest pursued by the interference and a relevant CJEU ruling. ${ }^{132}$ In two of the four cases in which the ECtHR also applied the doctrine in an EU-related case, Kokkelvisserij and Povse, it examined the possibility of rebuttal somewhat more elaborately, but in neither judgment was the EU criticized in any way nor was there any indication that protection had not been up to scratch. ${ }^{133}$ Although the ECtHR eventually also concluded in Avotinšs that the presumption could not be rebutted, it needed no less than nine paragraphs to arrive at that conclusion and, for the first time, came close to concluding that protection had been manifestly deficient. ${ }^{134}$

Article 34(2) of the Brussels I Regulation is again of great relevance here; in particular, the rule that a judgment (which should, in principle, not be recognized) can be recognized nevertheless when the defendant could have challenged the judgment but did not. Considering that the applicant failed to appeal the Cypriot judgment, the question was whether he had the possibility thereto. The Latvian courts neither answered this question nor the question of the burden of proof with regard to the existence and availability of appeal, even though Article 6(1) of the ECHR required them to verify these matters, according to the Court. ${ }^{135}$ Instead, they simply assumed that the burden of proof lay with the applicant or that appealing was possible. ${ }^{136}$ This approach could, according to the ECtHR, 'in theory' lead to the finding that the protection of the applicant's defence rights had been manifestly deficient. ${ }^{137}$ However, in the specific circumstances of the applicant's case, the ECtHR did not make this finding. ${ }^{138}$ It was possible for the ECtHR to criticize the Latvian courts for not verifying whether the applicant could have appealed the Cypriot judgment and for not answering the question of the burden of proof, even though these courts had no discretion, because the domestic courts did not carefully establish the factual circumstances that determined which of the two options in Article 34(2) of the Brussels I Regulation they had to choose.

Although the ECtHR criticized the domestic courts, and not the EU, and although it eventually avoided concluding that there was no equivalent protection, it showed its willingness to scrutinize carefully decisions of domestic courts 
implementing EU law (as in the Dhahbi/Schipani line of cases), even when they do not have discretion. Considering the important role of domestic courts in the EU legal system-for example, because they provide remedies to individuals for breaches of EU law ${ }^{139}$ - the ECtHR's careful scrutiny may be interpreted as a signal that the presumption of equivalent protection should not be taken as a given. In sum, the ECtHR again barked when stating that, in theory, the presumption could be rebutted because the protection was manifestly deficient_-something which it has never concluded before. It however did not bite, because it eventually upheld the presumption in the applicant's case. ${ }^{140}$

\section{CONCLUSION}

The examination of the recent developments that govern the relationship between the two highest European courts since Opinion 2/13 paints a mixed picture. The strictness of the ECtHR in Avotinšs depends very much on the part under consideration. On the one hand, the ECtHR rather easily assumes that the EU legal system offers equivalent protection and downplays the necessity for national courts to request a preliminary ruling from the CJEU. On the other hand, the ECtHR is stricter when it comes to the question whether the presumption that equivalent protection in the case at hand existed can be rebutted because the protection was manifestly deficient and on the specific point of mutual trust. The implicit reaction of the ECtHR to Opinion 2/13 can be seen in the latter two points: the ECtHR clarifies that the autonomy of EU law is not unlimited and it can, therefore, be concluded that the ECtHR seems to apply the Bosphorus doctrine somewhat more strictly than before Opinion 2/13 in comparison with the handful of judgments in which it dealt with the doctrine previously. Furthermore, it seems that the ECtHR wanted to show its dissatisfaction with Opinion 2/13, but without entering into open warfare. A similar conclusion can be drawn from the way in which Luxembourg has dealt with the ECHR and the case law of the ECtHR. Also, here one can discern a mixed bag with judgments that show a willingness on the part of the CJEU to autonomously interpret the Charter without regard to Strasbourg (J.N.), while other judgments show considerable respect and comity towards the ECtHR (Aranyosi).

The tone of the dialogue has thus become a bit harsher on both sides, albeit in a subtle way, for the courts continue to listen, defer, show respect and prevent conflict. The characterization of the relationship between the two courts before Opinion 2/13 (Section 2.C), therefore, still applies, but should be nuanced. This confirms that, as was indicated in Section 2.C, they can indeed change their mindset if they so wish. However, the analysis of the developments also demonstrates that, even in ever complex times and even after the great disappointment that Opinion 2/13 has been to the ECtHR, the courts have managed to avoid outright conflict. Although the precise character of the courts' future relationship will remain uncertain and even though concerns will continue to exist (Section 2.C), the relationship between the two

139 See Bosphorus, supra n 1 at para 164.

140 See also Johansen, 'The Bosphorus Presumption Is still Alive and Kicking: the Case of Avotiņš v. Latvia' PluriCourts Blog, 24 May 2016, available at: jus.uio.no/pluricourts/english/blog/stian-oby-johansen/ 2016-05-24-avotins-v-latvia.html [last accessed 21 December 2016]; Bergé, supra n 89. 
European courts is likely, considering what it has gone through already and what is at stake, to be resilient in the future too.

\section{ACKNOWLEDGEMENT}

The authors would like to thank professor J.H. Gerards for her valuable comments on earlier drafts of this article. 